\title{
Research Use Exemptions to Patent Infringement for Drug Discovery and Development in the United States
}

\author{
Alicia A. Russo and Jason Johnson \\ Fitzpatrick, Cella, Harper \& Scinto, New York, New York 10104-3800 \\ Correspondence: arusso@fchs.com
}

Experiments with patented compounds or processes are sometimes necessary for Food and Drug Administration approval of a small-molecule drug, biologic, or medical device. The law exempts certain research and development activities using these patented compounds or processes. The two exemptions are (1) a judicially created exemption developed through case law and (2) an exemption created by the Hatch-Waxman Act (the "safe harbor" provision). This article analyzes the history of these exemptions and how the courts have interpreted their scope and provides future perspectives on protecting research and development activities from liability.

ormally, performing experiments with patented products or processes during research and development is an act of patent infringement. Experiments with patented compounds or processes, however, are sometimes necessary to obtain approval by the Food and Drug Administration (FDA) to market a product containing a small molecule, biologic, or medical device. The law exempts certain experimental activities during research and development that would normally be considered patent infringement. The two exemptions are (1) a judicially created exemption developed through case law and (2) an exemption created by the Hatch-Waxman Act (the "safe harbor" provision). Understanding how courts determine if experimental activities fall within these exemptions is necessary for any company or university considering the use of a patented invention in its research.

This article deals with each exemption separately. The judicially created exemption is discussed first. The judicially created exemption is a narrow exemption, reliance upon which is not likely to be fruitful. Next, the statutory exemption is discussed. The statutory exemption, that is, the safe harbor provision, was created by Congress in 1983 as part of the Hatch - Waxman Act. The boundaries of the safe harbor provision have been interpreted by the courts, including the scope of preclinical activities that qualify, the scope of postapproval activities that qualify, whether activities related to biologics applications apply, and whether research tools qualify. In some of these areas, the guidance is clear. In others, the law is still developing. Understanding

Editors: Salim Mamajiwalla and Rochelle Seide

Additional Perspectives on Intellectual Property in Molecular Medicine available at www.perspectivesinmedicine.org

Copyright (C) 2015 Cold Spring Harbor Laboratory Press; all rights reserved; doi: 10.1101/cshperspect.a020933

Cite this article as Cold Spring Harb Perspect Med 2015;5:a020933 
A.A. Russo and J. Johnson

where the clarity and ambiguity lie is important before performing drug discovery and development.

\section{THE JUDICIALLY CREATED EXPERIMENTAL USE EXEMPTION TO PATENT INFRINGEMENT}

The judicially created experimental use exemption is a narrow one. What activities do or do not fall within the exception is determined based on the purpose of the experimentation-if the experimentation is for commercial or business purposes, it is not exempt. Because patents provide a right to exclude others from making, using, offering for sale, selling, or importing the invention, allowing unfettered use of another's patent rights would run contrary to the incentives for obtaining a patent. The quid pro quo of the right to exclude, conferred when a patent is granted, is the full disclosure of an invention, permitting others to learn from the inventor's work in order to make future advances or discoveries. This balance shapes the narrow types of experimental uses that are exempt from patent infringement.

The experimental use exemption was first articulated by the Supreme Court in 1813:

[I] $t$ could never have been the intention of the legislature to punish a man, who constructed such a machine merely for philosophical experiments, or for the purpose of ascertaining the sufficiency of the machine to produce its described effects. ${ }^{1}$

This articulation of the exemption was modified over time: "[it is] well-settled, that an experiment with a patented article for the sole purpose of gratifying a philosophical taste, or curiosity, or for mere amusement, is not an infringement of the rights of the patentee." 2 The uses allowed are thus akin to someone being curious about how something works and taking it apart to understand. Using that knowledge solely for the purpose of financial gain, however, is not allowed:

${ }^{1}$ Whittmore v. Cutter, 29 F. Cas. 1120, 1121 (C.C.D. Mass 1813) (No. 17,600) (emphasis added).

${ }^{2}$ Poppenhusen v. Falke, 19 F. Cas. 1048, 1049 (C.C.S.D.N.Y. 1861) (No. 11,279) (emphasis added).
The interest to be promoted by the wrongful employment of the invention must be hostile to the interest of the patentee... Thus where it is made or used as an experiment, whether for the gratification of scientific tastes, or for curiosity, or for amusement, the interests of the patentee are not antagonized, the sole effect being of an intellectual character in the promotion of the employer's knowledge or the relaxation afforded to his mind. But if the products of the experiment are sold, or used for the convenience of the experimentor, or if the experiments are conducted with a view to adaptation of the invention to the experimentor's business, the acts of making or of use are violations of the rights of the inventor and infringements of his patent. ${ }^{3}$

The exemption cannot be so broad that it contradicts the purpose of a patent - to prevent anyone else besides the inventor from making, using, or selling the invention. Several cases have tested the boundaries of the judicially created exemption. In all of those instances, however, the judicially created exemption remained narrow. See, for example, Roche Products, Inc. v. Bolar Pharmaceutical Co. (733 F.2d 858, 862-864) (Fed. Cir. 1984); Embrex, Inc. v. Service Engineering Corp. (216 F.3d 1343, 1349) (Fed. Cir. 2000); and Madey v. Duke University (307 F.3d 1351, 1355-1356, 1360-1363) (Fed. Cir. 2002).

Application of the Judicially Created Experimental Use Exemption to Patent Infringement for Generic Drug Approvals

Patent protection for drug products, medical devices, and biologic products is critical to the companies marketing and selling those products. Prior to 1983, if a patent covered any drug product or device, that patent prevented others from performing any work to obtain FDA approval prior to the expiration of those patents-unless that work was permitted by the experimental use exemption. Although there was arguably a public benefit from allowing this type of work to be exempt, that benefit was not deemed a sufficient reason for courts to exempt this research; see Roche v. Bolar (733 F.2d 858).

${ }^{3}$ W. Robinson, The Law of Patents for Useful Inventions, $\$ 898$ (1890) (emphasis added). 
In the case of Roche v. Bolar, Roche developed, marketed, and sold the prescription sleeping pill Dalmane ${ }^{\circledR}$. Roche owned a patent for the chemical compound flurazepam hydrochloride, the active ingredient in Dalmane ${ }^{\circledR}$. Bolar wanted to market and sell a generic version of Dalmane ${ }^{\circledR}$. Roche sued Bolar to prevent Bolar from using Roche's patented compound to gain FDA approval of its generic Dalmane ${ }^{\circledR}$ prior to the expiration of the patent covering flurazepam hydrochloride. Bolar argued that its use was an experimental use allowed by the exemption and, because public policy favored access to generics drugs, argued that experiments conducted to create generic drugs should be exempt from patent infringement. Neither argument was persuasive to the Federal Circuit.

The court ruled that whenever experiments were performed for business purposes, those experiments were not exempt. "[T]ests, demonstrations, and experiments which are in keeping with the legitimate business of the alleged infringer are infringements for which experimental use is not a defense." ${ }^{4}$ Bolar was in the business of marketing and selling generic drugs. Because Bolar's experiments were solely for business purposes, those experiments could not be exempt: “Bolar may intend to perform 'experiments,' but unlicensed experiments conducted with a view to the adaption of the patented invention to the experimentor's business is a violation of the rights of the patentee to exclude others from using his patented invention."

Even though allowing Bolar's experiments would provide the public with generic drugs sooner, this reason was not strong enough to avoid patent infringement. Congress addressed the lack of any exemption for generic drug testing shortly after the decision in Roche v. Bolar by passing the Drug Price Competition and Patent Term Restoration Act (informally known as the Hatch-Waxman Act), which contains an experimental use exemption for these types of exper-

\footnotetext{
${ }^{4}$ Roche v. Bolar (733 F.2d at 863) (emphasis added) (internal quotations omitted).

${ }^{5}$ Ibid.
}

iments. This exemption and its scope are discussed below.

Although the legitimate business of a company may change, as long as the experiments are conducted for any commercial purpose, those experiments are not exempt; see Embrex (216 F.3d 1343). Embrex had licensed a method patent from the U.S. government regarding a process for the inoculation of birds against disease through in ovo vaccine injections. After entering into the license, Embrex began developing machines to perform the inoculations on a large scale. Service Engineering Corp. (SEC) is a device manufacturer in this area. After learning of Embrex's in ovo vaccine work, SEC approached Embrex about using one of its devices to perform a step in the inoculation process. Embrex declined the offer, after which SEC attempted to design around the Embrex patent. Based on this work, Embrex sued SEC for patent infringement for the first time. The case eventually settled.

Undeterred, SEC continued its attempts to build an in ovo injection device. SEC eventually succeeded in building an in ovo injection device prototype, performing tests with the prototype, and soliciting orders for the prototype. SEC never sold a machine. Embrex learned of SEC's testing and marketing attempts and sued SEC again. SEC argued that its actions were an allowed experimental use because they were merely scientific experiments and no actual sales occurred. The Federal Circuit did not find these arguments persuasive.

The court found that SEC's experiments were strictly for commercial purposes. The fact that SEC did not successfully sell a machine did not make the experimentation allowable. If the use has the "slightest commercial implication," it is not allowed. ${ }^{6}$ SEC's use was experimentation to create a machine that it could sell for profit. Because SEC's use "in the guise of 'scientific inquiry" " had "definite, cognizable, and not insubstantial commercial purposes," it was an infringing use. ${ }^{7}$

\footnotetext{
${ }^{6}$ Embrex (216 F.3d at 1353) (concurrence).

${ }^{7}$ Embrex (216 F.3d at 1349).
} 
A.A. Russo and J. Johnson

Roche v. Bolar and Embrex are just two examples of how narrowly the Federal Circuit views the judicially created experimental use exemption. For companies in the business of making and selling products, it is unlikely that any experimentation will ever fall within this exemption. But are all experiments created equal?

Experimentation by Nonprofits or Universities May Be for Their Legitimate Business or for Commercial Purposes and Fail to Be Exempt

Should experimentation by universities be treated differently under the judicially created experimental use exemption because universities are not for-profit institutions? According to the Federal Circuit in Madey, the answer appears to be no; see Madey (307 F.3d 1351).

John Madey was a professor at Stanford University with a highly regarded laser research laboratory. Madey was the inventor of several patents related to the use of lasers in research. Duke University recruited Madey, and eventually he moved his research laboratory to Duke. Some years after his arrival, Madey and Duke had a dispute, which led to his departure. The equipment from his research laboratory, covered by Madey's patents, stayed behind at Duke. People at Duke continued to use some of this equipment. Madey sued Duke for patent infringement based on this use. Duke argued that because it was a nonprofit institution its use should fall within the experimental use exemption. The court found, however, that the nonprofit status of a university does not automatically allow unfettered experimental use.

Although a university may fund or allow research projects with arguably no commercial application, these activities further the legitimate business objectives of the university. Research projects may increase the stature of universities and help attract grants, students, and faculty. " $[S]$ o long as the act is in furtherance of the alleged infringer's legitimate business and is not solely for amusement, to satisfy idle curiosity, or for strictly philosophical inquiry, the act does not qualify for the very narrow and strictly limited experimental use defense."8

Thus nonprofits, although not commercial in nature, can have a legitimate business objective. In the case of universities, it appears that any research being conducted could potentially be for its legitimate business purpose and thus not exempt.

\section{Summary of the Judicially Created Experimental Use Exemption}

The judicially created experimental use exemption is very narrow. One reason why the exemption has been interpreted so narrowly may be to preserve the essence of a granted patentthe right to exclude others from making, using, offering for sale, selling, or importing the invention during the life of the patent. Some experimentation is exempted to attempt to strike a balance between the interests of inventions and the advancement of scientific progress. If the experimentation is related to a legitimate business interest or for commercial purpose, it is not likely to be the type of experimentation that is exempted. Because this exception is so narrow, companies, nonprofits, or universities that want to practice a patented invention as part of their experimental research should carefully consider whether it is advisable to rely on this experimental use exception.

\section{THE EXPERIMENTAL USE EXEMPTION CREATED BY THE HATCH-WAXMAN ACT - THE SAFE HARBOR PROVISION}

The Drug Price Competition and Patent Term Restoration Act (Hatch-Waxman Act), Pub. Law No. 98-417, 98 Stat. 1585 (1984) (codified in relevant part at 35 U.S.C. $\$ 271(\mathrm{e}))$ sets up a system to "balance the need to stimulate innovation against the goal of furthering the public interest." The law achieves this balance with the inclusion of a safe harbor provision, found in 35 U.S.C. $\$ 271(\mathrm{e})(1)$. The relevant portion of

\footnotetext{
${ }^{8}$ Madey (307 F.3d at 1362).

${ }^{9}$ H.R. Rep. No. 98-857 (Aug. 1, 1984), reprinted in 1984 U.S.C.C.A.N. 2686, 2714
} 
$\$ 271(\mathrm{e})(1)$ provides: “It shall not be an act of infringement to make, use, offer to sell, or sell within the United States or import into the United States a patented invention ... solely for uses reasonably related to the development and submission of information under a Federal law which regulates the manufacture, use, or sale of drugs or veterinary biological products."10

The safe harbor provision has the same general effect as the judicially created experimental use exemption-to permit certain activities that would normally be considered patent infringement. \$271(e)(1), however, deals specifically with activities related to the "manufacture, use, or sale of drugs." Although the scope of this exemption has been the focus of many litigations since its passage about 30 years ago, it is still in many ways in flux.

\section{The Safe Harbor Provision Covers More than Drugs}

On its face, $\$ 271(\mathrm{e})(1)$ may appear to relate only to "drugs," that is, drug products. That, however, is not the case. The U.S. Supreme Court has interpreted “drugs" in $\$ 271(\mathrm{e})(1)$ broadly, so that it would include research related to not only small-molecule drug products, but also medical devices and biologics (see Eli Lilly \& Co. v. Medtronic, Inc. (496 U.S. 661) (1990)).

"Uses reasonably related to the development and submission of information under a Federal law" are exempt under the safe harbor provision. According to the Supreme Court, "a Federal law" does not refer to a specific portion of a federal law, that is, only the federal law dealing with FDA approval of drug products. It is instead interpreted broadly, in part to encompass the dual purpose of the Hatch-Waxman Act.

As discussed by the court in Eli Lilly, the Hatch-Waxman Act was designed to address two "distortions" to the time period (formerly 17 years from the date the patent issued, now 20 years from the date of the filing of a U.S. patent application) an inventor has to prevent others from making, using, offering for sale, selling, or importing his or her invention caused by the

${ }^{10} 35$ U.S.C. $\$ 271(\mathrm{e})(1)$ (emphasis added). need for drug products, medical devices, and biologic products to seek premarketing approval (i.e., FDA approval). The first distortion the Hatch-Waxman Act sought to rectify was the loss of patent life at the beginning of the period. For instance, a company that owned a patent for an active ingredient in a drug product had to gain FDA approval before it could market and sell that drug product. Performing the work necessary to gain FDA approval can take many years. The clock of the patent term, however, did not stop. During this time, the patent holder could not reap any benefits of its patent because it could not market a product without FDA approval. The Hatch-Waxman Act sought to alleviate this distortion by giving a patent-term extension in certain circumstances to account for the time it takes to obtain FDA approval.

The second distortion the Hatch-Waxman Act addressed was the de facto extension of the patent's life by virtue of the fact that generic companies also need to seek FDA approval to market and sell their generic products. Because a patent prevents anyone else from making, using, or selling the product or device covered by the patent, any company that wanted to make a generic version could not perform any testing to gain FDA approval until the patent expired. This process took time and, in effect, extended the patent term because no other company could market a generic drug product until it had obtained FDA approval. \$271(e)(1) of the HatchWaxman Act addresses this distortion by allowing companies to perform the testing needed to obtain regulatory approval prior to the expiration of the patents covering the drug product. This safe harbor provision exempts certain kinds of experimentation from patent infringement so that a generic drug product can in theory be launched the day the patents covering the branded drug product expire.

These two corrections to the patent term are meant to be complementary-certain products are allowed a patent-term extension if regulatory review is lengthy, and patent infringement of those same products is exempted for generic products to gain FDA approval prior to patent expiration. In the case of medical devices, patents are also eligible for a patent-term extension 
A.A. Russo and J. Johnson

because of lengthy FDA review. Therefore, experimentation to obtain FDA approval for a medical device is exempt.

Having interpreted "Federal law" in the safe harbor provision, the attention of the courts turned to what uses are "reasonably related to the development and submission of information under a Federal law." When a branded drug product has a patent covering the active ingredient and a generic drug company performs bioequivalence testing with the active ingredient for FDA approval of its generic product, for example, this is most likely to be considered "reasonably related to the development and submission of information under a Federal law." Although there is some guidance on the scope of "reasonably related," there remains inconsistency in how the term is interpreted. Mainly, the focus has been on when during research and development the experiments are conducted.

\section{Preclinical Experiments under the Hatch-Waxman Act}

There are multiple phases in the research and development of drug candidates, from early drug discovery involving high-throughput screening of thousands of compounds to testing conducted years after FDA approval. At what point along this spectrum will the safe harbor provision protect the use of patented products or methods in experimental research? Unfortunately, there are no bright lines to be drawn on either end.

On the drug discovery side, preclinical testing, including the screening of candidate compounds, may be protected by the safe harbor provision according to the Supreme Court in Merck KGaAv. Integra Lifesciences I, Ltd. (545 U.S. 193) (2005).

In the late 1980s, Merck funded research by David Cheresh at the Scripps Research Institute regarding angiogenesis, which plays a role in certain cancers and rheumatoid arthritis. Through this research, Cheresh discovered that certain peptides, known as RGD peptides, could inhibit angiogenesis. With his funding by Merck set to expire, Cheresh came to a new research agreement with Scripps. Under the Scripps agreement, Merck would produce peptides and
Scripps would test the peptides as potential drug candidates. Once a primary candidate was identified, Merck would perform preclinical tests as part of the Investigational New Drug application (IND) seeking FDA approval to perform clinical testing.

When testing under the Scripps agreement began, the research was focused on three RGDspecific peptides. Preclinical tests were performed with each of the three peptides to determine which was most promising to use for clinical trials. Based on the testing, one of the peptides was selected. Merck filed an IND with the FDA seeking approval for clinical testing with the selected peptide. Integra owned patents related to RGD peptides and sued Merck, Scripps, and Cheresh for patent infringement based on the preclinical testing with the three RGD peptides. The Supreme Court found that the preclinical testing was exempt from patent infringement under the safe harbor provision.

The Court understood the safe harbor provision to give a "wide berth for the use of patented drugs in activities related to the federal regulatory process." ${ }^{11}$ As long as the information being generated is "reasonably related" to the "development and submission of any information" under the federal laws governing FDA approval, that work is protected.

Reasonably related research is not limited to clinical trial research. Preclinical work can also be exempt. Although the information presented in an IND and the FDA's analysis is geared toward the safety of drugs, other preclinical information is relevant to the FDA's decision. This information includes testing on pharmacology, toxicology, pharmacokinetics, and metabolism, and both in vivo and in vitro testing. The FDA does a broad analysis of all the information available to determine whether or not the drug is safe enough to place in humans. Even information that is generated by testing not conducted according to FDA good laboratory practices can be considered and reviewed. Thus, preclinical information generated for a particular drug

\footnotetext{
${ }^{11}$ Merck KGaA v. Integra (545 U.S. at 202).
} 
would be "reasonably related" and therefore protected by the safe harbor.

The Merck case presented a slightly different issue. Testing was conducted on not just one compound, but three. Only one candidate, along with its testing, was selected and presented to the FDA. The data for the other compounds were not given to the FDA. Integra argued that because more than one compound was being tested and that testing was screening to select the best candidate, this was not preclinical work, but pure experimental research. Based on these facts, the Supreme Court still found the preclinical activity protected.

Testing performed even in the late stages of development is still a process of trial and error. Failures can occur, and have occurred, as late as the clinical stage. Thus, the success or failure of the experimental work cannot be the determinative factor for what activity falls within the safe harbor. Flexibility is necessary. The safe harbor contemplates this_-work that is "reasonably related" is exempt.

In certain instances, work on patented compounds that are either not the ultimate subject of an FDA submission or not ultimately submitted to the FDA fall within the safe harbor. If it is known that the compounds being tested work through a particular biological process, for example, inhibit a certain cell receptor, and produce a particular physiological effect, for example, prevent angiogenesis, and the intent was to generate the data to submit to the FDA, those experiments are exempt. "At least where a drugmaker has a reasonable basis for believing that a patented compound may work, through a particular biological process, to produce a particular physiological effect, and uses the compound in research that, if successful, would be appropriate to include in a submission to the FDA, that use is reasonably related to the development and submission of information under Federal Law." 12

All of the experimental work performed by Merck, Scripps, and Cheresh was performed after it was recognized that the particular RGD

\footnotetext{
${ }^{12}$ Merck KGaAv. Integra (545 U.S. at 206) (emphasis added) (internal quotations omitted).
}

peptides being tested could block cell surface receptors ("a particular biological process") and inhibit angiogenesis ("a particular physiological effect”). Because there was intent to develop one of the compounds and knowledge that the compounds already had a desired effect, the testing was not "basic scientific research" to search for a drug candidate. "Basic scientific research on a particular compound, performed without the intent to develop a particular drug or a reasonable belief that the compound will cause the sort of physiological effect the researcher intends to induce, is surely not 'reasonably related to the development and submission of information' to the FDA." "13

Even though preclinical testing can be exempt, the line between preclinical experiments and basic scientific research is unknown because there are any number of different scenarios in which drugs are used in preclinical testing. To be "reasonably related" under the safe harbor provision, if preclinical testing is being performed on multiple compounds, at a minimum: (1) how the compounds work should be understood (biological process); (2) the effect of activating the biological process should be understood (physiological effect); and (3) there must be intent to submit the information to the FDA for approval of a product. Without proof for all three, the preclinical experiments are unlikely to be exempt under the safe harbor. Exactly how much proof is required is still unclear and will have to be developed through further case law or a change in the statute.

\section{Postapproval Experiments and the Safe Harbor Provision-A Split in Whether or Not They Are Exempt}

Experimentation does not stop once an application has been either submitted or approved by the FDA. In some instances, the FDA requires additional testing. An inconsistency has emerged in what postapproval testing falls within the safe harbor provision. Two cases in particular have caused confusion: Classen Immu-

\footnotetext{
${ }^{13}$ Merck KGaA v. Integra (545 U.S. at 205-206) (emphasis added).
} 
notherapies, Inc. v. Biogen IDEC (659 F.3d 1057) (Fed. Cir. 2011) and Momenta Pharmaceuticals, Inc. v. Amphastar Pharmaceuticals, Inc. (686 F.3d 1348) (Fed. Cir. 2012).

Classen, decided first by the Federal Circuit, appears to exclude any postapproval testing from the safe harbor provision. In that case, Classen researched how earlier vaccination of infants against infectious diseases could affect the later occurrence of chronic immune-mediated disorders such as diabetes or asthma. Classen applied for and received several patents regarding methods to determine the correct vaccination schedule and administer vaccines to lower the risk of chronic immune-mediated disorders. Biogen and GlaxoSmithKline (collectively referred to as "Biogen") conducted various studies to determine if any associations existed between certain childhood vaccinations and the risk of developing type 1 diabetes, including whether vaccination timing influenced the risk. The studies were conducted after FDA approval of all drug products being studied. Classen sued Biogen based on these postapproval studies. According to the Federal Circuit, the safe harbor exemption did not apply because these were postapproval studies.

The court, taking into account what it believed to be the purpose of the Hatch-Waxman Act, came to a more narrow interpretation of what activities are exempted. In its view, the Hatch-Waxman Act concerned "premarketing approval of generic drugs" to "facilitate market entry upon patent expiration." "14 Biogen's activities were not undertaken to generate information for approval of a generic product. Because the safe harbor provision provides "an exception to the law of infringement in order to expedite development of information for regulatory approval of generic counterparts of patented products," the safe harbor would not apply to postapproval activities. ${ }^{15}$ Even though this information would be "routinely reported" to the FDA after marketing approval, this was not the type of activity Congress meant to exempt.

\footnotetext{
${ }^{14}$ Classen v. Biogen (659 F.3d at 1071-1072).

${ }^{15}$ Classen v. Biogen (659 F.3d at 1070).
}

In excluding postapproval activity wholesale from exemption, the court did not take into account the situation in which the FDA required the postapproval activities. This broad exclusion of all postapproval activity could create liability for many companies that must perform studies for the FDA to be allowed to market their products. This could present a potentially untenable position for a company to be in.

About a year after Classen, the Federal Circuit rendered its Momenta decision, with what appears to be the opposite outcome. In Momenta, Amphastar applied for approval of a generic version of Lovenox ${ }^{\circledR}$. The active ingredient in Lovenox ${ }^{\circledR}$ is enoxaparin, which is a low-molecular-weight version of heparin. Heparin in turn is a polysaccharide that can vary in length depending on how it is produced. This variability raised issues with FDA approval of a generic enoxaparin because a generic version must have the same ingredient as the reference drug. The FDA used five criteria to confirm that a generic enoxaparin had the same active ingredient as Lovenox ${ }^{\circledR}$. For example, one criterion was proof that the generic enoxaparin contained disaccharide building blocks. Because of the potential risk that each batch of generic enoxaparin could vary in length, the FDA required proof that every batch of generic enoxaparin met the five criteria. The requirement to meet all five criteria would continue as long as Amphastar wanted to market and sell generic enoxaparin-in other words, this would be postapproval, FDA-required activity.

Momenta owns several process patents related to determining the number of disaccharide building blocks in enoxaparin. Momenta filed suit against Amphastar based on its activities to prove its generic enoxaparin was the same as Lovenox ${ }^{\circledR}$. The court found Amphastar's activities exempt under the safe harbor provision.

Performing its own analysis of the legislative history and case law interpreting the safe harbor provision, the court took a much broader view of the safe harbor provision than the court in Classen. The court in Momenta read the safe harbor provision to not limit or narrow the exemption to just FDA laws regarding Abbreviat- 
ed New Drug Application (ANDA) approvals. Instead, the court found that the safe harbor provision uses broad, flexible language to define the scope of the exemption. A submission under any federal law that "regulates the manufacture, use, or sale of drugs" is exempted. Limiting the scope to just the federal law regarding ANDAs would be contrary to the plain language of the safe harbor provision. The Federal Food, Drug and Cosmetic Act (FFDCA) is the law that addresses not only ANDA applications, but INDs, New Drug Applications, and medical device applications as well. As long as the activities are "reasonably related" to the "the development and submission of information" under the FFDCA, those activities are exempt. Amphastar's activities were such activities.

Although Amphastar was required by the FDA to prove that each batch of its generic enoxaparin met the five criteria, it was not required to submit its proof to the FDA. Rather, Amphastar was required to keep all batch records for 1 year and have those records available for FDA inspection at any time. The requirement to perform the testing and maintain the records made the activities reasonably related to the development and submission of information to the FDA.

Classen and Momenta came to two different conclusions regarding whether or not postapproval activities are exempt under the safe harbor. Parties in both cases asked the Supreme Court to provide clarity. The Supreme Court declined in both cases. Under current law, it appears that if experiments are conducted and there is no specific FDA mandate to do so, those activities will not be exempt. Apart from this, what postapproval activities, beyond those directly mandated by the FDA, will be exempt remains unclear.

\section{BIOLOGICS LICENSE APPLICATIONS AND THE STATUTORY SAFE HARBOR PROVISION}

Although the above-discussed cases focused on small-molecule products, the safe harbor provision should apply equally to experiments performed for submissions to the FDA regarding biologic products. Most biologic products fit within the broad definition of "drugs" in the FFDCA:

(g)(1) The term "drug" means (A) articles recognized in the official United States Pharmacopoeia, official Homoeopathic Pharmacopoeia of the United States, or official National Formulary, or any supplement to any of them; and (B) articles intended for use in the diagnosis, cure, mitigation, treatment, or prevention of disease in man or other animals; and (C) articles (other than food) intended to affect the structure or any function of the body of man or other animals; and (D) articles intended for use as a component of any article specified in clause (A), (B), or $(\mathrm{C}){ }^{16}$

In view of this definition, experiments related to either a biologic drug product or process to make a biologic product should be evaluated using the same rules as small molecules. See, for example, Amgen, Inc. v. International Trade Commission (565 F.3d 846, 852, 853) (Fed. Cir. 2009), evaluating activities relating to a Biologics License Application using the safe harbor provision.

\section{RESEARCH TOOLS AND THE SAFE HARBOR PROVISION}

One interesting aspect of the Merck case was that the Supreme Court explicitly stated that its decision did not address whether or not the use of "research tools" falls within the safe harbor provision. Despite that statement, how the court determined that the experiments fell within the safe harbor can be useful to determine what activities with research tools patents may be exempt.

Research tools are useful for general experimentation to discover potential compounds, that is, "basic scientific research." Experimentation with research tools in this way would be outside the safe harbor. But as was the case in Merck, research tools may be used in directed preclinical activities that could be protected by the safe harbor provision. No case has directly addressed the specific question of whether experimentation using patented research tools is eligible for the safe harbor provision. Despite this,

${ }^{16} 21$ U.S.C. $\$ 321(\mathrm{~g})(1)$. 
A.A. Russo and J. Johnson

there are several Federal Circuit cases that, although not addressing the broader question, provide insight on how experimentation with research tools might be looked at when deciding if an exemption applies. See, for example, Proveris Scientific Corp. v. InnovaSystems, Inc. (536 F.3d 1256) (Fed. Cir. 2008), Classen, and Momenta.

In the Proveris case, Proveris owned a patent for an aerosol spray apparatus that can be used to deliver measured drug doses in nasal spray pumps or inhalers. InnovaSystems made and sold a device called an optical spray analyzer (OSA), which it sold to companies to deliver aerosol doses of drug products. Innova's OSA was used in several FDA submissions as the delivery device for aerosol doses of the drug products. The OSA itself, however, was not subject to FDA review or approval. Proveris claimed that the use of Innova's OSA to deliver aerosol doses of drug products infringed its patent. Innova argued that because the OSA was manufactured for use with FDA-approved drugs, its activities fell within the safe harbor provision. The court did not agree.

It is undisputed that experimentation with patented medical devices is eligible for protection under the safe harbor provision (see Eli Lilly (496 U.S. at 672-679)). This is not, however, a blanket protection. The experimentation must still be "reasonably related to the development and submission of information under a Federal law." ${ }^{17}$ If the device itself is not subject to FDA approval, experimentation with that device is not a reasonably related use protected by the safe harbor provision.

The Hatch-Waxman Act addressed two distortions (discussed above): the loss of time for regulatory approval at the front end of the patent life and the gain of time at the end of the patent from the delay in gaining generic FDA approval. Because neither distortion was applicable, the safe harbor did not exempt Innova's work.

For Innova, the OSA did not need to be reviewed or approved by the FDA. Only the drug products it delivered were subject to FDA review

${ }^{17} 35$ U.S.C. $\$ 271(\mathrm{e})(1)$ and approval. Thus, there was no delay as a result of FDA approval that had to be addressed. For Proveris, there was also no FDA approval barrier to overcome. Any aerosol delivery products it made also did not need FDA approval. Without a need for FDA approval of its products, Proveris did not lose any time off the life of the patent as a result of regulatory approval.

Based on the logic of Proveris, it appears that if FDA approval is not required to make, use, or sell a medical device, any activities to make, use, or sell that device are unlikely to be exempted.

At the present time, any analysis regarding the use of research tool patents should focus on what experimentation will be performed. Basic scientific research to screen for potential compounds will not be an exempted use. Using research tools for focused preclinical tests, clinical testing, or required postapproval FDA testing is more likely to be exempt than a use to broadly screen for potential compounds or to conduct non-FDA-mandated postapproval activities.

\section{FUTURE PERSPECTIVES}

Although there is some ambiguity in the law, there are several actions that can be taken to aid in the protection of certain types of experiments from patent infringement liability. First, formulating an early action plan with the end goal being submission to the FDA may allow companies to assert that at least some aspects of the work were reasonably related to develop information to submit to the FDA. Second, having an FDA mandate for the experimentation, whether that be via direct request to the FDA or based on specific FDA regulations, may also be a factor in determining whether the experimentation is exempt. Third, companies that wish to assert an experimental use exemption when screening multiple compounds should have a clear understanding of the biological properties and physiological action of those compounds prior to testing. Finally, the experiments and reasons for the experiments should be properly documented in the event that it becomes necessary to show that the experiments were reasonably related to information submitted to the FDA. 


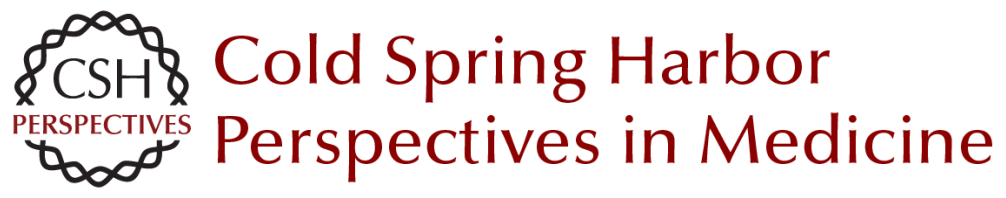

\section{Research Use Exemptions to Patent Infringement for Drug Discovery and Development in the United States}

Alicia A. Russo and Jason Johnson

Cold Spring Harb Perspect Med 2015; doi: 10.1101/cshperspect.a020933 originally published online October 30, 2014

\section{Subject Collection Intellectual Property in Molecular Medicine}

Patentability of Stem Cells in the United States Sarah E. Fendrick and Donald L. Zuhn, Jr.

Inventorship and Authorship

Antoinette F. Konski and Linda X. Wu

The Patentability of Stem Cells in Australia Jenny Petering and Prue Cowin

Impact of America Invents Act on Biotech

Intellectual Property

Amanda Murphy, Michael Stramiello, Jonathan Stroud, et al.

Introduction to Intellectual Property: A U.S.

Perspective Amanda Murphy, Michael Stramiello, Stacy Lewis, et al.

The Role of Regulatory Agencies and Intellectual Property: Part I Kevin E. Noonan

Canada's Patented Medicines (Notice of Compliance) Proceedings and Intellectual Property Henry Bian and Conor McCourt

Patentability of Genes: A European Union Perspective Paul Cole
The Impact of Myriad on the Future Development and Commercialization of DNA-Based Therapies and Diagnostics

Michele Wales and Eddie Cartier

Protecting Traditional Knowledge Related to

Biological Resources: Is Scientific Research

Going to Become More Bureaucratized?

Prashant Reddy and Malathi Lakshmikumaran

Protecting Trade Secrets in Canada Noel Courage and Janice Calzavara

Inherent Anticipation in the Pharmaceutical and

Biotechnology Industries

Michael Goldman, Georgia Evans and Andrew Zappia

The Role of Regulatory Agencies and Intellectual

Property: Part II Kevin E. Noonan

Baseball Bats and Chocolate Chip Cookies: The Judicial Treatment of DNA in the Myriad Genetics Litigation lan Binnie and Vanessa Park-Thompson

The Impact of Myriad and Mayo: Will

Advancements in the Biological Sciences Be

Spurred or Disincentivized? (Or Was Biotech

Patenting Not Complicated Enough?) Jennifer Gordon

Trade Secrets in Life Science and Pharmaceutical Companies

Tara Nealey, Ronald M. Daignault and Yu Cai

For additional articles in this collection, see http://perspectivesinmedicine.cshlp.org/cgi/collection/ 